\title{
Factors Stimulating Internationalisation of Firms: An Attempted Holistic Synthesis
}

\author{
Magdalena Belniak
}

\begin{abstract}
A B S T R A C T
Objective: The main goal of this paper is the critical and synthetic analysis of internationalisation process factors, with reference to business management. It presents a systematic review of the most important relational ideas in regard to factors of firm-level internationalisation.

Research Design \& Methods: The text includes the synthesis of previous academic studies and results of empirical researches on internationalisation factors.

Findings: The motives for going international are explained in reference to external and internal factors. Different definitions of understanding external factors of internationalisation of firms are discussed, among them (i) framework factors (market, cost, governmental, competitive and additional factors), (ii) conditioning factors (factor and demand conditions, related and supporting industries, firm strategy, structure and rivalry) as well as (iii) general environment factors (economic environment, demographic environment, political and legal environment, technological, natural and socio-cultural environment).
\end{abstract}

Implications \& Recommendations: Internal factors of internationalisation are mostly rooted in the resource-based view. Motives for going international mainly depend on top management team, international resources and firms specifics.

Contribution \& Value Added: The paper underlines that there are numerous factors, both external and internal, which influence international activities of firms. Despite the fact that the decision to internationalize is focused on specific motives and goals, the role of managers is crucial.

\section{Article type: original literature review}

Keywords:

Internationalisation; internationalisation factors; international

JEL codes: triggers; international incentives, motives for going international

\section{Suggested citation:}

Belniak, M. (2015). Factors Stimulating Internationalisation of Firms: An Attempted Holistic Synthesis. Entrepreneurial Business and Economics Review, 3(2), 125-140. doi: 10.15678/EBER.2015.030209 


\section{INTRODUCTION}

Existing literature reveals that there are large disparities between opinions concerning factors of internationalisation and their significance for businesses. The factors of the internationalisation with reference to business management are quite differently perceived in the literature. Such notions or categories as factors, motives, triggers, change agents, conditions or determinants are treated rather superficially, sometimes even interchangeably (Wach, 2012, p. 69; Daszkiewicz \& Wach, 2013, pp. 36-37). The main reason for this is the fact that these categories are more difficult to quantify than others. Thus, a short systematic review of the relational ideas with reference to factors of firm-level internationalisation is indeed worth performing.

The objective of this study is the synthesis and grouping of previous theoretical studies, as well as the results of empirical researches on internationalisation factors. This study is based on the review and analysis of the academic literature, source materials and research evidence's examination concerning factors of internationalisation process of firms, recognized under different approaches and mainstreams (from classical school of management to the latest school of international entrepreneurship).

\section{MATERIAL AND METHODS}

The study is based on extensive literature review and analysis of the academic studies, as well as source materials. It synthesizes examination of research evidence concerning factors of internationalisation process of firms, recognized under different approaches and mainstreams. In its main objective, the article focuses on identifying the most important factors that stimulate international activity of firms.

\section{LITERATURE REVIEW AND THEORY DEVELOPMENT}

\section{The Nature and Demarcation of Internationalisation Factors}

Chomątowski (1986, p. 12) stresses that both conditions (determinants) as well as factors share a number of common features, although there are differences between them. The influence of conditions "is less direct and bears a potential character," and their use leads to development, otherwise we deal with unused conditions. Then, "the factors these are the ones among conditions, which as a result of economic decisions, have been engaged (...) and in a measurable manner affect in a given time", which means that "factors are a sub-set of a set of conditions", although "we may find opinions that conditions are a sub-set of a set of factors" (Chomątowski, 1986, p. 13). Chomątowski also states that conditions "generally have a static character," and "from the point of view of their dimension as economic size they are mostly resources", while factors "have more dynamic nature and usually have dimensions of streams". Summing up, we may assume that "the factors are sometimes understood as the known elements or forces, whose action is possible, if the appropriate conditions are met. The conditions are those circumstances which support and enable occurrence of factors as well as affect given factors" (Chomątowski, 1986, p. 14). 
In the literature the broadest concept is the category of factors, which with reference to internationalisation, may take the nature of motives, incentives or conditions. In this context, factors can be treated as determinants, i.e. conditioning factors, however, the direction of their influence as well as strength with which they act (Łach, 2012, p. 186) should be defined in details, although, as Łach observes, determinants are understood in the literature in two ways, whereas their second meaning refers to the criteria for selection of certain alternatives. Similarly, Bieńkowski $(2008$, p. 8) treats factors as determinants (presenting them alternatively in brackets), adding that they may act passively (neutrally) or actively (positively or negatively).

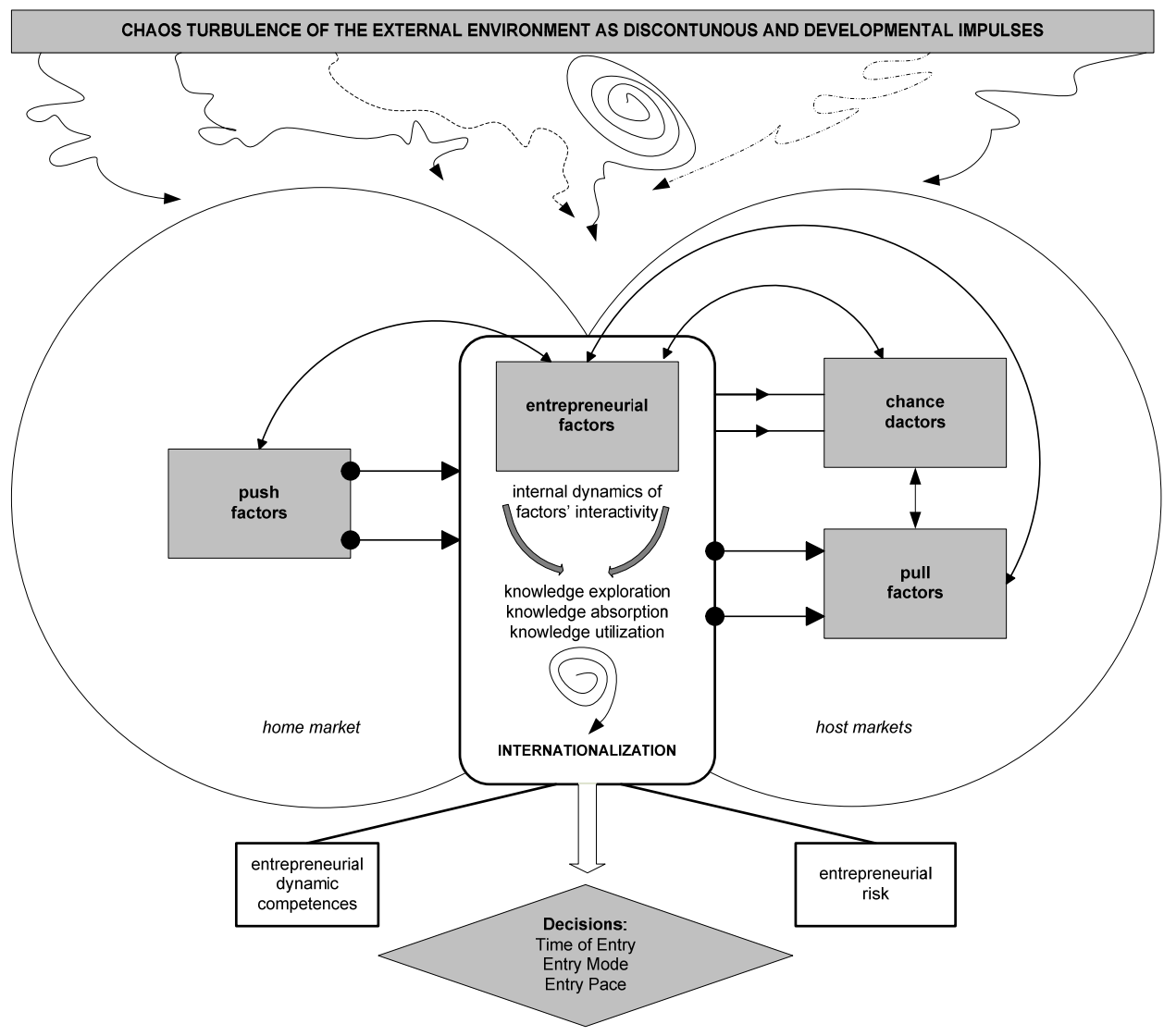

Figure 1. Internationalisation factors configuration according to Wach Source: Wach (2012, p. 75).

The distinction between proactive (pull) factors and reactive (push) factors of internationalisation are rooted in international marketing studies. This classification was prepared by Albaum (2002). Later on, this concept was developed into a very popular 4element typology (Daszkiewicz \& Wach, 2014): push factors, pull factors, chance factors, entrepreneurial factors (Figure 1). The group of stimulating push factors that force firms to make a decision about internationalisation occurs when a home market is saturated, 
but in particular when there is overproduction and an increased competitive game. The group of pull factors characterizes firms which strongly focus on profits and actively search for a potential market abroad: make use of the economy of scale, or take up any challenges of internationalisation. The chance factors takes place when a firm makes use of an accidental situation (e.g. international order), while entrepreneurial factors are based on a continuous improvement and the growth theory of the firm, where the latest step is the international growth (Wach, 2012, p. 74).

Hollensen (2007, p. 298) distinguishes 16 factors of internationalisation dividing them into four groups and classifying them differently. These factors (Figure 2) may influence the process of internationalisation, acting either in a positive or a negative way, and simultaneously proposes his own model of entry modes choice (Daszkiewicz \& Wach, 2013, p. 46). The model of Hollensen is very interesting as it stems from the management science and the theory of organisation, with the noticeable addendum of economics theory (among other the transaction costs), and is based on four main decisive factors: (i) internal factors, (ii) desired mode characteristics, (iii) transactionspecific factors, and finally (iv) external factors (Hollensen, 2007, p. 298).

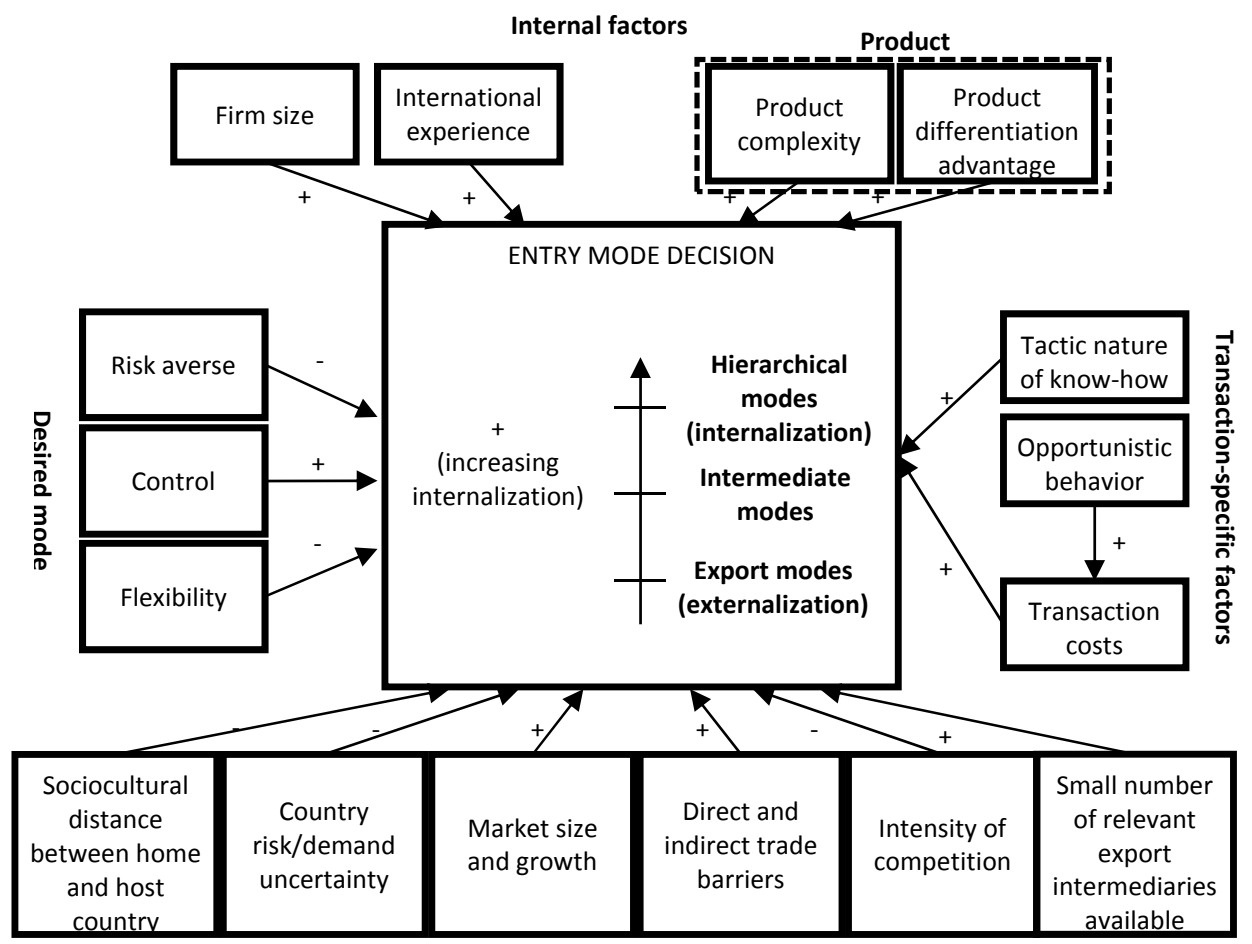

External factors

Figure 2. Internationalisation factors according to Hollensen Source: Hollensen (2007, p. 298).

Alternatively, Rymarczyk (2012, p. 180) proposes a 5-element division of internationalisation factors into supply, cost, market, political and strategic motives. And 
so, the supply motives are characteristic for firms from countries without their own natural resources, both mineral and agricultural, and their extraction is often accompanied by processing. This is due to the fact that the transportation costs are lower when semi-fabricates and partially processed products are imported as well as due to the environmental protection in the home country during the process of partial processing (Rymarczyk, 2004, pp. 65-68).

Another equally important supply motive from the firm perspective, especially in the case of high cost of wages in the home market, is the desire to gain non-qualified or lowqualified labour force. This motive is directly connected with the the cost motive, i.e. lowering the costs of production and, thus, increasing the profits of a firm. In some countries, apart from lower labour costs, there are also lower costs of raw materials, lands, environmental protection expenses, lower taxes and economies of scale, reductions as well as custom allowances in relation to import. The cost benefits may be achieved with the aid of cheaper loans and easy access to financial recourses.

The market motives which stimulate international activities of businesses include: stagnation in the home market and dynamic growth and development of foreign markets, unused production capacity, diminished or disappearing demand for a given product (Rymarczyk, 2004, pp. 60-62). In the home market, the motives can include increased competition or intention to gain competitive advantages over competitors, tough import restrictions in the current markets as well as durable deviations of the exchange rate and intention to reduce the risk.

The political motives are usually divided into two groups regarding a policy pursued by the home country and a policy of a host country in which the foreign expansion is planned.

Daszkiewicz and Wach (2013, pp. 36-37), sorting the terminology issues out, define the term of internationalisation factors very broadly, they understand this term as "motives of internationalisation defined in the literature as incentives (triggers, motives) and conditions of internationalisation, including internal conditions (organisational) as well as external conditions (these of domestic and international environments), naturally from the perspective of management sciences, especially regarding strategic management, and this approach to the undertaken theme has been developed since the 1960s. Their integrated perspective (in accordance to holistic approach) is understood as not only a few selected factors, but the whole spectrum of internationalisation factors. Therefore, the factors were structured into different categories and analysed against number of criteria (Table 1). The internationalisation factors can be categorised as:

a) internal factors, in accordance with the theory of organisation and management science, in particular resource-based and competences view as well international entrepreneurship approach,

b) external factors, in accordance with the strategic management approach:

- home-market factors (domestic environment),

- host-market factors )international environment), divided into three dimensions:

- macroenvironment (general environment),

- mesoenvironment (regional environment and/or industrial environment),

- microenvironment (competitive environment, task environment), including also the network approach. 
Table 1. The identification of basic factors for business internationalisation

\begin{tabular}{|l|l|}
\hline $\begin{array}{l}\text { Factors } \\
\text {-its identification and grouping }\end{array}$ & $\begin{array}{l}\text { Management concept } \\
- \text { theoretical basis of distinction }\end{array}$ \\
\hline $\begin{array}{l}\text { Domestic environment factors } \\
\text {-including regional factors }\end{array}$ & International marketing approach \\
\hline International environment factors Intermediate factors \\
\hline \multicolumn{2}{|c|}{ Internal factors } \\
\hline $\begin{array}{l}\text { Industry-related factors } \\
\begin{array}{l}\text { The role of formal and informal networks in } \\
\text { the internationalisation process }\end{array}\end{array}$ & Networking approach \\
\hline $\begin{array}{l}\text { Enterprises specifics } \\
\text { Biographic approach in management } \\
\text { Ethnographic approach in management }\end{array}$ \\
\hline $\begin{array}{l}\text { Firm resources and competences: } \\
\text { resources sensu stricto } \\
\text { - innovation potential } \\
\text {-competences and capabilities }\end{array}$ & Resource-based and competences approach \\
\hline Organizational structure and changes to it & Structural approach \\
\hline $\begin{array}{l}\text { Internationalisation's strategy and its content } \\
\text { on particular levels }\end{array}$ & Strategic approach \\
\hline $\begin{array}{l}\text { Attitude and skills of the entrepreneur/ } \\
\text { manager }\end{array}$ & International entrepreneurship approach \\
\hline
\end{tabular}

Source: own study.

Firms are learning and gaining new knowledge on international markets and the global environment, which decreases risk and increases commitment to the new market, as a result of expanding knowledge and experience (Wach, 2014b). According to the resource-based view, both knowledge and learning processes are the most important factors in building the competitive advantage (Doryń \& Stachera, 2008, p. 101). As Doryń and Stachera (2008) discuss increasing internationalisation involvement causes that benefits related to internationalisation begin to appear, and the increase of them is greater than the increase of costs. An opposite concept assumes that at low levels of internationalisation, increased international engagement means improved economic conditions for firms, despite the initial costs associated with the lack of knowledge on the new market (Wach, 2014b).

\section{External Factors of the Internationalisation Process}

Łoboda (2007, pp. 34-42) notes that the increasing globalisation of the economy is a driver of business international activities. It influences small and medium-sized enterprises very positively, those usually operating only on a local scale, as it creates the possibility of the rapid internationalisation and increased pace of development of their competencies. Global standards serve as tools for improving competitiveness, they increase the efficiency of global economy, determine social and ecological dimensions of international trade, shaping new forms of global management of the world economy (Nadvie \& Waltring, 2004, p. 53). 
A firm location is also one of the most commonly considered elements of competitive advantage. It is especially important for the functioning of firms in clusters (Porter, 1998). Obłój (2002, pp. 97-123) includes the location as the important natural sources of competitive advantage, with particular attention to the location of production and sales, and access to resources, understood as raw material production. Many businesses choose to move their production facilities to countries where the labour costs are cheap (or highly specialized), so as to, in the context of creating a competitive advantage, use two sources at the same time - the location and the access to resources, which naturally result in a competitive advantage. The very access to productive resources depends not only on the location of production, but often also on relationships with the environment. These relationships can have a very significant impact on the competitive advantage of a firm, especially in situations where results of the firm largely depend on these relationships, for example: functioning in a particular industry and gaining confidence or the issue of informal dependencies (Śliwiński, 2011, p. 39).

According to Gorynia (2007, p. 50) “(...) the external factors have the original meaning and, in a sense, primary importance (...)". In order to illustrate the importance of external factors Gorynia used Porter's models - related to a broadly understood competition - as well as Yip's model - stemming from the industry specific conditions of a business strategy. According to Yip's model the firm's choice of strategy is based on main characteristic attributable to the immediate environment of an organisation. Gorynia (2007, p. 50) distinguishes the following groups of factors that stimulate a firm to go international (so called the framework factors):

- market factors (GDP, life style, consumers preferences, broadly understood globalization of lifestyle, development of advertisement, media, etc.),

- cost factors (technological progress, economy of scale, development of international shipping, shorter product lifecycle, R\&D costs increase, newly industrialized countries),

- governmental factors (removing of tariff barriers and non-tariff barriers, development of a world trade institution, establishing of several economic institutions, privatization and denationalization of many industries, implementation of a free market system, new vibrant and buoyant economies),

- competitive factors (global alliances, increase of global structures of international interdependence, appearance of born global's, increase of the number of countries on a competitive market, constant increase of turnover in the world trade and participation of foreign entities in the ownership structure), as well as,

- additional factors (revolutionized IT and telecommunications market), facilities referring to business travels, globalization of financial markets),

- Rymarczyk (2012, pp. 268-269) discusses that the direct situation in foreign market has the most significant impact on decisions concerning whether go international or not. Export is worth undertaking in case of a small geographical distance (Wach, 2015), potential low entry barriers as well as import supported by a country of destination. However, indirect export or licensing ought to be taken into consideration in case of a significant culture distance (Wach, 2015b), risk of political activity, economic stagnation of the country of destination, or simply in case of a low potential of the foreign market. In contrast, in a foreign market such factors as: 
favourable economic conditions, weak currency, low production costs, small competition and the great potential of the market, favourable political conditions, i.e. stability, support of direct foreign investments, low political risk as well as a large geographical distance (Wach, 2015a), and connected with it high costs of delivery, will encourage a firm to make decision on foreign direct investments.

Gorynia and Jankowska (2011), in their research, faced issues related to benefits and risks associated with Polish accession to the euro zone. And so, the spectrum of benefits and risks for Polish businesses, resulting from Poland's adoption of the euro is quite broad, but with a predominance of benefits, as joining the monetary union (EMU), will raise the level of competitiveness of firms. Polish accession to the monetary union shall decisively change the conditions in which Polish firms operate, and consequently also change their competitive strategies. Gorynia et al. (2011) emphasize that internationalisation involves the problem of perception of Polish businesses in the international arena, and Poland's accession to the euro zone should positively affect the image of Polish trade partners and intensify international trade cooperation.

Porter (1990) distinguishes four groups of conditions, which altogether provide an incentive for a business to go international, especially into a given foreign market. These are (i) factor conditions, (ii) demand conditions, as well as (iii) related and supporting industries, and (iv) firm strategy, structure and rivalry (Daszkiewicz \& Olczyk, 2014, pp. 36-37). Additionally, Porter (1994) distinguished two other elements which have influence on a decision referring to the location of the business activity in another country, i.e. chance factors (e.g. risk, terrorist attack) as well as governmental factors (supporting policies). All these factors constitute "Porter's diamond model for competitive advantages of nations". Lisiński (2004, p. 74) underlines that functioning of a business is a result of interaction of the nation's general features, which are very important for the international context of each business. Such national features, forming the external business environment, build a certain context in which businesses are established and compete with each other, and the context facilitates or obstructs them to gain a competitive advantage in international markets.

For firm-level internationalisation, it is crucial to analyse the international external environment and to monitor changes, as these determinants to choose a proper strategy and entry modes (Duliniec, 2005, pp. 86-87).

The business external environment might be classified differently. One of the most popular typologies distinguishes three layers, namely the general environment (sometimes known as the macroenvironment), the task environment (sometimes known as the microenvironment) as well as a mesoenvironment (Wach, 2008, pp. 29-36) - as a kind of the intermediate environment between the macroenvironment and the microenvironment - usually identified with the regional environment from the perspective of management theory ${ }^{1}$. Duliniec $(2005$, p. 87 ) advices to pay special

\footnotetext{
${ }^{1}$ According to Wach (2012, p. 117), meso-analysis may be considered dualistically - sectorally (it applies to sectors, branches, or industry markets) or regionally (on the level of economic regions and very often administration sub-regions). It is worth mentioning that the meso-level, from the point of view of economy, should be interpreted differently than in the management. In the management sciences the sector factors are
} 
attention to such conditions as differences concerning a level of economic development, participation of a given country in the interstate economic contracts, technological differences, infrastructural differences, differences concerning a level of urbanization as well as social, cultural, language and other differences connected with communication and ethical standards in the international business. This concept is based on the PEST/PESTLE analysis. Wach (2014a, pp.18-20) points out two main dimensions of external factors stimulating internationalisation, namely (i) general environment - from both home (domestic) market and host (international market (markets) perspectives as well as (ii) industry-related factors.

Wach (2014a, pp. 18-19) analyses external general business environment from local to truly global level taking into consideration different aspects from the perspective of the PLESCET analysis (Figure 2).

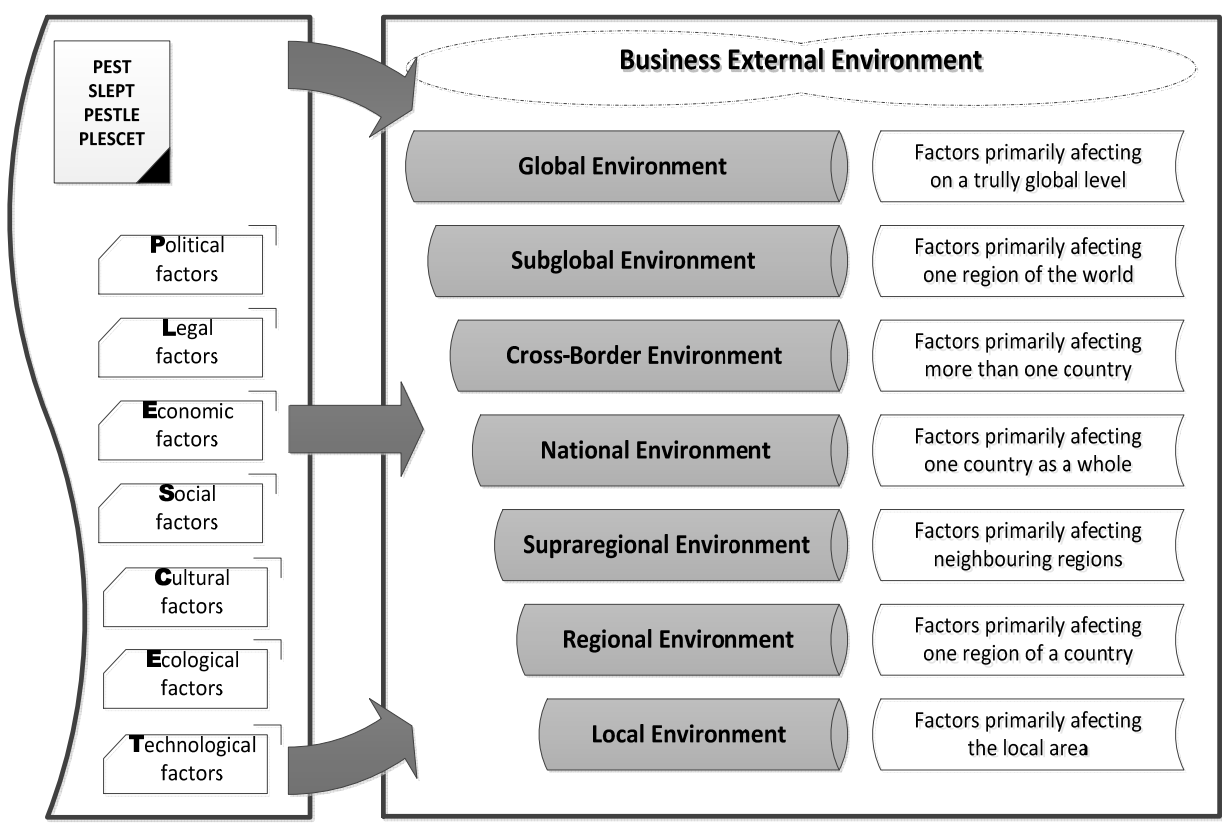

Figure 3. External general environment factors for internationalisation according to Wach Source: (Wach, 2014a, p. 18).

According to Doryń (2011, p. 100), the macroeconomic factors (the economic environment), which have influence on internationalisation of firms, include two groups of variables - demand (exchange rate, external demand) and costs variables (prices, salaries and wages, interest rates). Such indices as terms of trade, real export transaction prices, import transaction prices as well as real effective exchange rates are of extremely important meaning for firm internationalisation (Doryń, 2011, p. 102). 
The demographic environment plays also an important role in the process of internationalisation (Wiktor, Oczkowska \& Żbikowska, 2008, p. 53-54). The political and legal environment, in particular durability of a political and legal conditions, should be considered an important stimulus for going international (Wiktor et al., 2008). A significant emphasis should be placed on the extent to which the governments can control or limit actions of the foreign investors as well as entice or even discourage entry into a given market by foreign ownership companies. Czinkota \& Ronakainen (2004, p. 144) state the level of political risk is inversely proportional to the level of economic development of the individual countries.

The technological environment is also a significant element of the international environment. It involves such factors as transport infrastructure, possibilities of transmitting and processing information (ICT), level of development of a banking system and financial institutions, development of some service sectors, the mass media (Duliniec, 2004, pp. 79-83). Currently, the fastest changes in the business external environment are made due to the technology progress, thus the low level of technological progress of a country may become a restriction for foreign businesses to expand in. The general possibilities and costs of international activities are determined also by the natural environment (Wiktor et al., 2008, pp. 61-62) which affects the choice of a type of activity on the individual markets. The elements of a natural environment, which can be significant while making a decision whether go or not international, include the set of climactic and geographical factors characteristic for a given region (e.g. climate, natural topography, availability of raw resources). These elements may have a significant influence on distribution of goods as well as restrict development of its network and even prevent it.

A major challenge in the process of firm-level internationalisation is determined also by the socio-cultural environment, because every culture influences consumer behaviour in the market, and its essence, the specific nature and numerous, complex practical implications are often difficult to grasp for foreigners. Businesses in the international markets are influenced by such cultural elements as language, religion, habits of good consumption, a sense of aesthetics as well as attitudes to foreign products (Wiktor et al., 2008 p. 63).

\section{Internal Factors of the Internationalisation Process}

There are many internal variables that determine international activities of firms. Wach (2014a, p. 21) states that internal internationalisation factors are rooted in resourcebased view and points out three basic groups of factors such as (i) internal resources, (ii) capabilities and competences and (iii) entrepreneurial knowledge and experience. The latter are rooted in international entrepreneurship theory (Wach \& Whermann, 2014; Wach, 2014b). Internal determinants conditioning effectiveness of companies in international markets involve, inter alia, decisions made by the firm at various management levels, especially those which are accompanied by strategies for their use in practice (Kraśnicka, Głód \& Głód, 2008, p. 47). Particular emphasis is placed on specific assets possessed by the firm because they enable smooth functioning among competitors 
Zahra and George (2002, pp. 271-273) undertook research on internal determinants of international entrepreneurship, and presented a set of three factors with the greatest impact on firm-level internationalisation based on the resource-based view, namely:

- top management team, in particular, experience of working abroad, origins of the founders and foreign education and a vision of global development of the organization,

- internal resources, especially those unique, expenditure incurred on research and development activities, ability to work in a network and reputation of the company,

- specifics of the firm, such as the size and age of the firm, location, legal form, testing business environment, financial strength and pro-development orientation.

\section{Entrepreneurial Attitude and Global Orientation of Entrepreneurs}

Among the internal factors, undoubtedly the most important one, contributing to accelerating the process of internationalisation is the human factor (top management team) - the owner, the founder, the entrepreneur. The path of internationalisation is determined by human beings, as they select the place and the right time for the international expansion. They have specific characteristics that determine the possibility of rapid international expansion; ability to innovate, acceptanc of a high level of risk, often having international experience and global business vision, and identifying corporate growth opportunities outside the home country (McDougall \& Oviat, 2000, p. 903). Knight \& Cavusgil (2004, p. 14) believe that any global vision of an entrepreneur can be explained by the influence of their education and international experience, therefore, earlier work experience is important, along with market expertise, the ability to recognize business opportunities, as well as the level and type of education, knowledge of foreign languages and the ability to select appropriate managers.

Other internal determinants of internationalisation include: unique knowledge, especially experimental learning acquired directly in the course of business run overseas (Wach, 2014b), as the knowledge that is available to the firm is one of the factors that does not only facilitate and accelerate foreign expansion, but also conditions successful operations on foreign markets (Johanson \& Vahlne, 2003, p. 22).

The attitude of top management team is an important variable determining internal activities of companies in international markets. Managers who want to effectively manage internationalized firms should be able to solve complex problems related to their functioning and also have the right attitude and certain personality traits that make up their international orientations defining strategic objectives of foreign actions and decisions regarding the allocation of resources in international markets (Johanson \& Vahlne, 2003, p. 105).

According to Perlmutter (Wach \& Wojciechowski, 2014) international orientation of managers can be represented by three personality types, which are ethnocentric, polycentric, regiocentric and geocentric orientations (the EPRG path).

The basics of ethnocentric orientation imply that practice and experience of the domestic market, as well as national standards of conduct, are of universal importance. The home country is the most important, home experts are more trustworthy and, with little international experience of executives, the so-called self-reference criterion is often used to make decisions based on domestic enterprise culture (Duliniec, 2004, p. 24). In 
this case, subsequent entry into foreign markets follows due to the strategy of focusing on domestic market activity - sequential expansion strategy (Karasiewicz, 2013, p. 106).

The polycentric orientation is represented by managers which have already reached further levels of internationalisation, have greater international experience and know that every new market requires a different approach. Firms operating in different markets best fitted to local characteristics become priorities, foreign branches are treated as separate business units, with a high autonomy of operation (Wiktor et al., 2008 , p. 148). Due to that, the polycentric orientation is associated with early entry to a foreign market and adapting entry strategies to external conditions.

In contrast, the geocentric orientation is a of a synthesis of both of the above discussed orientations. Top management team treats foreign markets as a common global market, while at the same time, they can notice similarities between markets and differences that make up the specificity of operation on the markets.

\section{Internal Resources and Competences}

Resources and competencies of firms are usually divided into tangible and intangible resources (Dess, Lumpkin \& Taylor, 2003, p. 9). The first category usually includes financial resources (financial flows, ability to raise capitals and credit capacity), physical resources (modern technology park or an advantageous location of production), technological resources (new forms of organization of production, patents, copyright, trade mark) and organization resources (effective process planning strategy, as well as visible development and control system). Whereas, intangible resources of a firm include human resources; experience and abilities of employees, trust, managerial skills, specific practices and procedures, and creativity, innovation corporate reputation and its perception by both suppliers and customers, and finally, organizational skills or inputoutput skills of employees, the ability to connect tangible and intangible resources using organizational processes in order to achieve the planned effect, and finally, remaining competencies of companies (Kraśnicka et al., 2008, pp. 48-49).

In recent years, the role of enterprise resources and sources of competitive advantage has changed. A particular attention is paid to the intangible resources, as in the era of information society, they have become the essential ones for fast-growing companies that build competitive advantage, in particular, on such resources as knowledge, skills and experience.

Thus, intellectual capital becomes a driver stimulating international activity of firms. It consists of human capital, organizational capital, market capital and innovation capital, i.e. the sum of intangible assets of a business (Ross \& Ross, 1997). Innovative activity is closely related to intellectual capital, because innovation is the result of a creative process which is the result of creative thinking of a human being. Potential of people is, thus, a foundation of effective functioning of firms, and a human being in an organization has become a prerequisite and a foundation of innovative and indispensable source of innovation.

Resources and skills are the base for the construction of core competencies and distinctive capacity of firms, and these are a great driver of international activity, they provide a competitive advantage in the market. Both competences and expertise lead to most of the variables most important to the results of businesses, such as quality, priceperformance ratio, or the ability to sell (Śliwiński, 2011, p. 45). 
Obłój (2007, p. 127) believes that core competencies are those skills, that are decisive in competition in the market, and unlike other competencies, it is not only difficult to acquire them, but also to replace them, or even imitate. They form the basis for companies' foreign expansion and acquiring new markets (Śliwiński, 2011, p. 46). Within international management, they are associated with acquiring special skills that are necessary for the company to achieve success in foreign markets.

The power to adjust competencies to strategy, strengthen competitiveness by minimizing costs and quality increase and by raising utility value, play a huge role in stimulating international business activity, along with the perception of key competences as strategic elements of companies' activities (Hamel \& Prahald, 1999, p. 190), as well as defining them in terms of international competitive advantage. Key competences are, however, dynamic, they change over time, so companies must strive to create the most appropriate response strategy in reaction to changing operating conditions and development (Tubielewicz, 2004, p. 186).

\section{CONCLUSIONS}

In conclusion, we can say that there are many factors, both external and those existing within the organisation, which stimulate international activities of fir. Not only the very process of internationalisation, but its pace or scope, including decisions on the choice of entry modes (Wach, 2014a). Specific methods of internationalisation (entry modes) differ in many respects, and can, at the same time, also be a selection criteria, e.g. extent of capital involvement, extent of management involvement, scope of provided control, scope risks involved and range of potential profits (Daszkiewicz \& Wach, 2013). However, the basis for a decision to internationalize is always focused on specific motives and goals. The first being a psychological category and relating to human behaviours in the organization. These may be economic reasons, as managers striving to increase income and job security, or intangible motives; as desire to achieve prestige, power, selfrealization, adventure, traveling abroad (Rymarczyk, 2012, p. 266). Thus, when resources and business external environment are the background factors determining strategic decisions on internationalisation, the role of managers is crucial as decisions made in firms are largely dependent on the managers themselves and their willingness to take the risk associated with international markets (Kraśnicka et al., 2008, p. 51).

\section{REFERENCES}

Albaum, G., Strandskov, J., \& Duerr, E. (2002). International Marketing and Export Management. 2nd ed. Harlow: Addison-Wesley Longman Publishing.

Ansoff, H.J. (1985). Zarzqdzanie strategiczne. Warszawa: PWE.

Bieńkowski, W. (2008) Konkurencyjność gospodarki kraju: próba rewizji determinant i miar; przyczyny zmian znaczenia czynników konkurencyjności (chapter 1). In W. Bieńkowski \& M. Weresa (Eds.), Czynniki i miary międzynarodowej konkurencyjności gospodarek w kontekście globalizacji - wstępne wyniki badań (Working Papers No. 284). Warszawa: Instytut Gospodarki Światowej Szkoły Głównej Handlowej.

Chomątowski, S. (1986). Rozwój przemysłu w świecie. Kraków: Akademia Ekonomiczna. 
Czinkota, M.R., \& Ronkainen, I.A. (2004). International Marketing. Mason: Thomson-SouthWestern.

Daszkiewicz, N., \& Olczyk, M. (2014). Competitiveness of the Visegrad Countries - Paths for Competitiveness Growth (chapter 2). In D. Kiendl-Wendner \& K. Wach. (Eds.), International Competitiveness in Visegrad Countries: Macro and Micro Perspective (pp. 33-52). Graz: Fachhochschule Joanneum.

Daszkiewicz, N., \& Wach, K. (2013). Małe i średnie przedsiębiorstwa na rynkach międzynarodowych. Kraków: Wydawnictwo Uniwersytetu Ekonomicznego.

Daszkiewicz, N., \& Wach, K. (2014). Motives for Going International and Entry Modes of Family Firms in Poland. Journal of Intercultural Management, 6(2), 5-18.

Dess, G.G., Lumpkin, G.T., \& Taylor, M.L. (2003). Strategic Management. Creating Competetive Advantage. New York: McGraw-Hill.

Doryń, W. (2011). Wpływ internacjonalizacji na wyniki ekonomiczne polskich przedsiębiorstw przemysłowych. Łódź: Wydawnictwo Uniwersytetu Łódzkiego.

Doryń, W., \& Stachera, D. (2008). Wpływ internacjonalizacji na wyniki ekonomiczne największych polskich przedsiębiorstw przemysłowych. Gospodarka Narodowa. 11-12, 95-115.

Duliniec, E. (2004). Marketing międzynarodowy. Warszawa: PWE.

Gomes, L., \& Ramaswamy, K. (1999). An empirical examination of the form of the relationship between multinationality and performance. Journal of International Business Studies, 30(1), 173-187.

Gorynia, M. (2007). Strategie zagranicznej ekspansji przedsiębiorstw. Warszawa: PWE.

Hamel, G., \& Prahald, C.K. (1999). Przewaga konkurencyjna jutra. Strategie przejmowania kontroli nad branżq̨ i tworzenie rynków przyszłości. Warszawa: Business Press.

Hollensen, S. (2007). Global Marketing: A Decision-Oriented Approach. 4th Edition. Harlow: Pearson Education.

Johanson, J., \& Vahlne, J.E. (2003) Business Relationship Learning and Commitment in the Internationalisation Process. Journal of International Entrepreneurship, 1(1), 83-101.

Johnson, J.E. (2004). Factors Influencing the Early Internationalisation of High Technology Startsups: US and UK Evidence. Journal of International Entrepreneurship, 2(1-2), 139-154.

Karasiewicz, G. (2013). Marketingowe strategie internacjonalizacji polskich przedsiębiorstw. Podejście holistyczne. Warszawa: Wolters Kluwer Polska.

Knight, G.A., \& Cavusgil, S.T. (2004). Innovation, Organizational Capabilities and Born Global Firm. Journal of International Business Studies, 35(2), 124-141.

Kraśnicka, T., Głód, G., \& Głód, W. (2008). Przedsiębiorczość międzynarodowa. Aspekty teoretyczne i praktyczne, T. Kraśnicka (Ed.). Katowice: Akademia Ekonomiczna w Katowicach.

Krupski, R. (2009). O szkole zasobów zarządzania strategicznego inaczej. Przeglqqd Organizacji. 3.

Lisiński, M. (2004). Metody planowania strategicznego. Warszawa: PWE

Łach, K. (2012). Kierunki badań nad determinantami struktury kapitału przedsiębiorstw w Polsce. Zeszyty Naukowe PTE. 12.

Łoboda, M. (2007). Lokalne przedsiębiorstwa na rynkach globalnych. In A. Sitko-Lutek (Ed.), Polskie firmy wobec globalizacji. Luka kompetencyjna. Warszawa: PWN.

McDougall, P.P., \& Oviat, B.M. (2000). International Entrepreneurship: The Intersection of Two Research Paths. Academy of Management Journal. 43(5), 902-906.

Nadvie, K., Waltring, F. (2004). Making Sense of Global Standards. In: H. Schmitz, \& E. Elgar (Eds.). Local Enterprises in the Global Economy. Chaltenham-Northampton. 
Obłój, K. (2007). Strategia organizacji. Warszawa: PWE.

Obłój, K. (2002). Tworzywo skutecznych strategii. Warszawa: PWE.

Porter, M.E. (1990). Competitive Advantage of Nations. Hampshire-London: Macmillan Press.

Porter, M.E. (1994). Strategia konkurencji. Metody analizy sektorów i konkurentów. Warszawa: PWE.

Porter, M.E. (1998). Clusters and the New Economics of Competition. Harvard Business Review. November-December.

Przybylska, K. (2013). Born global - Nowa generacja małych przedsiębiorstw. Kraków: Fundacja Uniwersytetu Ekonomicznego w Krakowie.

Ross, G., \& Ross J. (1997). Measuring your Company's Intellectual Performance. Long Range Planning.

Rymarczyk, J. (2004). Internacjonalizacja i globalizacja przedsiębiorstwa. Warszawa: PWE.

Rymarczyk, J. (2012). Biznes międzynarodowy. Warszawa: Polskie Wydawnictwo Ekonomiczne.

Śliwiński, R. (2011). Kluczowe czynniki międzynarodowej konkurencyjności przedsiębiorstw. Poznań: Wydawnictwo Uniwersytetu Ekonomicznego.

Tubielewicz, A. (2004). Zarzqdzanie strategiczne w biznesie międzynarodowym. Warszawa: Wydawnictwo Naukowo-Techniczne.

Wach, K. (2008). Regionalne otoczenie małych i średnich przedsiębiorstw. Kraków: Wydawnictwo Uniwersytetu Ekonomicznego.

Wach, K. (2012). Europeizacja małych i średnich przedsiębiorstw: rozwój przez umiędzynarodowienie. Warszawa: Wydawnictwo Naukowe PWN.

Wach, K. (2014a). Theoretical Framework of the Firm-Level Internationalisation in Business Studies (chapter 1). In A. Duréndez \& K. Wach (Eds.). Patterns of Business Internationalisation in Visegrad Countries - In Search for Regional Specifics (pp. 13-32). Cartagena: Universidad Politécnica.

Wach, K. (2014b). The Role of Knowledge in the Internationalisation Process: An Empirical Investigation among Polish Businesses (chapter 7). In D. Kiendl-Wendner \& K. Wach (eds), International Competitiveness in Visegrad Countries: Macro and Micro Perspectives (pp. 143158). Graz: Fachhochschule Joanneum.

Wach, K. (2015a). Entrepreneurship without Borders: Do Borders Matter for International Entrepreneurship? Problemy Zarzq̨dzania, 13(2[2]), 82-92.

Wach, K. (2015b). Impact of Cultural and Social Norms on Entrepreneurship in the EU: CrossCountry Evidence based on GEM Survey Results. Zarzqdzanie w Kulturze, 16(1), 15-29. doi: 10.4467/20843976ZK.15.002.3037

Wach, K., \& Wehrmann, C. (2014). Entrepreneurship in International Business: International Entrepreneurship as the Intersection of Two Fields (chapter 1). In A.S. Gubik \& K. Wach (Eds.). International Entrepreneurship and Corporate Growth in Visegrad Countries. Miskolc: University of Miskolc.

Wach, K., \& Wojciechowski, L. (2014). The Size and the Strategic International Orientation: The Use of EPRG Model among Polish Family and Non-Family Firms. Przedsiębiorczość i Zarzqdzanie, XV(7[1]), 143-156.

Wiktor, J., Oczkowska R., \& Żbikowska A. (2008). Marketing międzynarodowy. Zarys problematyki. Warszawa: PWE. 
Wołodkiewicz-Donimirski, Z., \& Marczewski, K. (2007). Kondycja ekonomiczna polskich eksporterów. Wyniki badań sprawozdań finansowych. Warszawa: Instytut Koniunktur i Cen Handlu Zagranicznego.

Zahra, S.A., \& George, G. (2002). International Entrepreneurship: The Current Status of the Field and Future Research Agenda. In M.A. Hitt, R.D. Ireland, S.M. Camp \& D.L. Sexton (Eds.), Strategic Entrepreneurship: Creating a New Mindset. Oxford: Blackwell Publishing.

\section{Author}

\section{Magdalena Belniak}

Assistant Professor at the Department of Entrepreneurship and Innovation at the Faculty of Economics and International Relations of the Cracow University of Economics (Poland). Her research interests include international management, internationalisation of firms and human capital.

\section{Correspondence to:}

Magdalena Belniak, PhD

Cracow University of Economics

Faculty of Economics and International Relations

Department of Entrepreneurship and Innovation

31-510 Kraków, ul. Rakowicka 27

magda.belniak@gmail.com

\section{Acknowledgements and Financial Disclosure}

The article came into being within the statutory research project no. 121/WE$\mathrm{KPI} / 03 / 2014 / \mathrm{S} / 4317$ entitled "Entrepreneurial and Innovation Processes as Catalyst and Stabilizers of Business Internationalisation" coordinated by K. Wach and financed by the Ministry of Science and Higher Education of the Republic of Poland with the funds allocated to development of research potential of the Faculty of Economics and International Relations of the Cracow University of Economics.

\section{Copyright and License}

This article is published under the terms of the Creative Commons Attribution - NonCommercial - NoDerivs (CC BY-NC-ND 3.0) License http://creativecommons.org/licenses/by-nc-nd/3.0/ 